À l'intersection des discours de spécialité :

hétérogénéité et unité

\title{
Transitivity and thematic structure in some early issues of the Philosophical Transactions
}

\section{David Banks}

\section{OpenEdition}

\section{Journals}

Electronic version

URL: http://journals.openedition.org/asp/1821

DOI: 10.4000/asp.1821

ISBN: 978-2-8218-0414-2

ISSN: 2108-6354

\section{Publisher}

Groupe d'étude et de recherche en anglais de spécialité

\section{Printed version}

Date of publication: 30 November 2010

Number of pages: $57-71$

ISSN: 1246-8185

\section{Electronic reference}

David Banks, "Transitivity and thematic structure in some early issues of the Philosophical

Transactions », ASp [Online], 58 | 2010, Online since 30 November 2013, connection on 02 November 2020. URL : http://journals.openedition.org/asp/1821 ; DOI : https://doi.org/10.4000/asp.1821

This text was automatically generated on 2 November 2020.

Tous droits réservés 


\title{
Transitivity and thematic structure in some early issues of the Philosophical Transactions
}

\author{
David Banks
}

\section{Introduction}

1 In general linguistics, it is accepted that synchronic studies can benefit from, and be informed by, diachronic considerations. Hitherto, diachronic studies have been rare in the field of Languages for Specific Purposes; those that have appeared have usually been in the sociolinguistics area, rather than in linguistic analysis as such (Atkinson 1999, Bazerman 1988, Gross et al. 2000, 2002, Valle 1999). But I believe that such studies can inform the study of the current situation and help us understand why specialized languages have come to be as they are. This article is part of my current research in this field, e.g., Banks 2009a, b, c, forthcoming a, b, c. Here, I shall first give some historical background, then look in detail at the issue of the Philosophical Transactions for 3 July 1665. I shall use techniques developed within Systemic Functional Linguistics to present a semantic categorization of themes in thematic structure, and an analysis of processes in transitivity, with a more detailed study of the participants in material process. I shall attempt to bring out the significance of the results by comparing them briefly with results for a comparable issue of a contemporaneous publication, the Journal des Sçavans.

\section{Historical context in general and Henry Oldenburg in particular}

2 The Philosophical Transactions was founded by Henry Oldenburg in 1665, and its first issue appeared in London on 6 March, only two months after the first issue of the Journal des Sçavans in Paris. Henry Oldenburg was born in Bremen in present-day 
Germany; the exact date is not known, but it is believed to have been about 1615 . Information on his early life is sketchy, but we know that he studied theology before coming to England in 1639. He remained there until 1648, earning his living as tutor to the children of rich families. In 1652 he went back to Bremen, but returned to England as a diplomat. In 1665 he became tutor to Richard Jones, a nephew of Robert Boyle, and in that capacity accompanied him on a tour of continental Europe, during the years 1657 to 1660 . In 1660 he became one of the first secretaries of the newly founded Royal Society, the other being Robert Hooke.

At this time most of the members of the Royal Society, and indeed scientists in general, were virtuosi, or gentleman amateurs in the sense that they had private financial means, and did not depend on their scientific activity to earn a living. Oldenburg, however, did not belong to this privileged group; he did have to earn his living and his stipend as secretary of the Royal Society was certainly not sufficient for that. The $£ 40$ per year which he received as secretary was probably conceived of more as expenses than a salary as such.

In the 17th century, there were two ways of disseminating new knowledge: books and letters. Books were long and costly to produce. Letters were quicker, and although, by their very nature, they were sent from individual to individual, they were not really private letters in the present day sense: it was understood that they could, and should, be copied, sent on, read at meetings, and so on. This practice was sufficiently well established for the fact of having been written in a letter to constitute a significant element in a priority dispute.

Oldenburg was an inveterate letter writer, and in this context had become the centre of a network of scientific correspondence. He had established many contacts during the tour of 1657-1660, and his position as secretary of the Royal Society served to increase and enhance the network of which he was the hub. It was in this situation that he conceived of the idea of creating a bulletin of information, or "intelligence", as he called it, which he could then sell as a means of increasing his income (Bluhm 1960, Hall 2002).

The Philosophical Transactions was published monthly from March onwards during its first year of publication, with a break from July to November, caused by the plague. These issues were made up of letters and extracts from letters, as well as some papers read at the Royal Society, some extracts or summaries of books, and some book reviews. Table 1 shows the distribution of these genre types for the issues of 1665 .

Table 1. Genre of items in Philosophical Transactions 1665

\begin{tabular}{|l|l|l|l|l|l|l|l|l|}
\hline & 6 Mar & 3 Apr & 8 May & 5 June & 3 July & 6 Nov & 4 Dec & Total \\
\hline news item & 9 & - & - & - & - & 1 & 2 & 12 \\
\hline letter or extract & - & 5 & - & 1 & 3 & 5 & 3 & 17 \\
\hline Royal Society paper & - & - & 4 & 1 & 1 & - & - & 6 \\
\hline book extract/summary & - & - & - & 4 & 1 & 4 & 1 & 10 \\
\hline book review & - & 1 & 3 & 2 & - & - & 1 & 7 \\
\hline
\end{tabular}




\begin{tabular}{|l|l|l|l|l|l|l|l|l|}
\hline list & - & - & - & - & 1 & - & - & 1 \\
\hline obituary & 1 & - & - & - & - & - & - & 1 \\
\hline editorial & 1 & - & - & - & - & - & - & 1 \\
\hline
\end{tabular}

7 It can be seen that of the 55 items, 17 (31\%) were letters or extracts from letters. There are also 12 news items (22\%), which were written up by Oldenburg himself, on the basis of information supplied in the letters he received. The first issue was compiled basically in this way, but he used this method comparatively rarely thereafter. The books from which he printed extracts, or summaries, or for which he supplied a review, were also received in his correspondence. We can therefore say that $84 \%$ of the contents of these issues of the Philosophical Transactions was directly based on Oldenburg's correspondence.

\section{This article}

This article will look at the issue for 3 July, the last to appear before the break caused by the plague, in more detail. The content of this issue is as follows:

- An Account, how Adits \& Mines are wrought at Liège without Air-shafts, communicated by Sir Robert Moray.

- A way to break easily and speedily the hardest Rocks, communicated by the same Person, as he received it from Monsieur Du Son, the inventor.

- Observables upon a Monstrous Head.

- Observables in the Body of the Earl of Balcarres.

- Of the designed Progress to be made in the Breeding of Silkworms; and the Making of Silk, in France.

- Enquiries concerning Agriculture.

9 The first item is an account of ventilation techniques in mines at Liège. The second describes a tool for breaking rocks. The third is a description of the dissection of the head of a deformed colt. This is followed by an autopsy report of the Earl of Balcarres. The fifth item is a book review; the book, written in French and published in France, concerns the silk industry in that country. The final item is a list of questions for a survey of English agriculture planned by the Royal Society.

\section{Theoretical framework}

10 I shall analyse this document using techniques developed in Systemic Functional Linguistics (Halliday 2004a, Banks 2005). In particular, I will analyse the thematic structure and the transitivity patterns.

11 Many linguistic theories provide for an analysis of the clause in terms of a theme and a rheme, which constitute the thematic structure. In systemic Functional Linguistics, the theme is defined as the speaker's starting point, and consists of an obligatory typical theme, which may be preceded by optional textual or interpersonal themes. The theme is encoded in English by being placed in initial position in the clause. 
12 In Systemic Functional Linguistics, transitivity has a rather wider meaning than is usual in other theories. It concerns the relationship between the process, encoded in the verbal group, the participants in the process, encoded as subject and complement, and, if there are any, the attendant circumstances.

\section{Thematic structure}

Thematic structure analyses the clause in terms of theme and rheme. An obligatory element of the theme is that part which functions as a major constituent of the clause (subject, circumstantial adjunct, predicator, or complement); this is called the topical theme. In previous work (Banks 2008a, 2009b) I distinguished 15 semantic categories for topical themes. Eight of these are relevant to the present study. These are given below, with examples of each from the sample. The relevant part of each example is in bold.

14 Obj:: the object of study or observation

At the mouth or entry of the Adit there is a structure raised of Brick, like a Chimney, some 28. or 30. foot high in all

The steeled end is so shaped, as makes it most apt to pierce the Rock, the Angles at that end being still to be made the more obtuse, the harder the rock is.

Exp.: the experiment or the experimental process. There are relatively few of these: despite the policy statements of the Royal Society, experimentation did not play a major role until rather later (Bazerman 1988).

The manner is, as followeth.

That the Belly of this Nobleman being opened, the 0 . mentum or Net was found lean and small: his Liver very big; the Spleen big also, filled with a black and thick humour.

Oth.: humans other than the author. This categorization does include an author category but there were no examples in this mini-corpus.

But to some it seemed to be a production of the matter designed for the Nose, but diverted by this Monstrous Conception: perhaps the Processus mammillares joined into one, and covered with a thin hairy skin.

He advertiseth, that if they be coupled longer than 9. or 10. hours, (which they will be, and that sometimes for 24 . hours together, if they be let alone) either the female will receive very great hurt by it, or much seed will remain in her belly.

Meta: references to other parts of the same text.

The Figure of the Fabrick, Chimney, and all the parts thereof being hereunto annexed, the rest will be easily understood.

This is the substance of what is contained in this French Author, published at Paris on purpose to promote the Making of Silk there, as well as it is practised already in other parts of that Kingdom;

Inter: references to other texts. There are only two examples in the sample, both of which occur in the item on the French silk industry.

In which Book, the method being represented, which that Great Prince Henry IV used in establishing the said Work and Trade together with the success thereof, and the advantages thence derived to his Subjects, the Author, from his own Experience, and long Practice, delivers (and seems to do it candidly) all what belongs in this business in four main heads.

Through the whole Book are scattered many not inconsiderable particulars, though perhaps known to most. 


\section{Table 2. Semantic categories of topical themes (Philosophical Transactions)}

\begin{tabular}{|l|l|l|l|l|l|l|l|l|}
\hline & Obj & Exp & Oth & Meta & Inter & Exist & Ment & Time \\
\hline Adits and Mines & 17 & - & - & 1 & - & - & 1 & - \\
\hline A Way to break Rocks & 20 & 2 & - & - & - & 1 & - & - \\
\hline Monstrous Head & 13 & - & 1 & - & - & - & - & 1 \\
\hline The Earl of Balcarres & 6 & 4 & - & 1 & - & - & - & - \\
\hline Breeding Silkworms & 25 & 6 & 5 & 2 & 2 & 1 & - & 6 \\
\hline Enquires concerning Agriculture & 42 & - & 2 & 2 & - & - & - & 4 \\
\hline Total & 123 & 6 & 8 & 6 & 2 & 2 & 1 & 11 \\
\hline \% & 77 & 4 & 5 & 4 & 1 & 1 & 1 & 7 \\
\hline
\end{tabular}

As can be seen, the dominant semantic category by far is the object of study, which accounts for about three-quarters of the themes. It might be thought that this is fairly natural given the nature of the texts involved, and that any other result would have been surprising. However, the extent to which this figure is significant can be brought out by comparison with figures from a comparable issue of the Journal des Sçavans. The Philosophical Transactions and the Journal des Sçavans are exactly contemporaneous: The first issue of the Journal des Sçavans came out on 5 January 1665, just two months before the first issue of the Philosophical Transactions. They both had the same objective of 
disseminating new knowledge. However, they were distinguished by two editorial choices. First, it was intended that the Journal des Sçavans cover the whole range of human knowledge, whereas the Philosophical Transaction was to be restricted to the area of natural philosophy, or what we would now think of as science and technology. Secondly, the Journal des Sçavans was basically a book review journal, whereas, as we have seen the Philosophical Transactions was based mainly on letters received by Henry Oldenburg. An analysis of the semantic categories of topical themes in the issue of the Journal des Sçavans for 9 March 1665, gives the results shown in Table 3.

Table 3. Semantic categories of topical themes (Journal des Sçavans)

\begin{tabular}{|l|l|l|l|l|l|l|l|}
\hline & Obj & Auth & Oth & Inter & Exist & Ment & Time \\
\hline Codex Regularum & - & 4 & 6 & 11 & 1 & 1 & - \\
\hline Iosephi Laurenti & - & - & - & 6 & - & - & - \\
\hline Contradictiones Apparantes & 3 & 1 & 1 & 2 & 1 & 2 & - \\
\hline Divers Plaidoyez & 3 & - & 8 & 3 & 3 & 5 & 1 \\
\hline Reflexions & - & 1 & 1 & - & 1 & 1 & - \\
\hline La Vie des la Ste Vierge Marie & - & - & 2 & 2 & 1 & - & - \\
\hline Lettre d'un Amy & 1 & 5 & 4 & 3 & 1 & 7 & - \\
\hline Total & 7 & 11 & 22 & 27 & 8 & 16 & 1 \\
\hline$\%$ & 8 & 12 & 24 & 29 & 9 & 17 & 1 \\
\hline
\end{tabular}

Here it can be seen that the dominant semantic categories are other texts and other humans. The other texts are mainly the books under review, and the other humans are usually the authors of those books. The point is not that these items appear frequently in the texts, which is only to be expected, but that it is precisely these items which are selected as themes. The object of study as theme is here relatively marginal. Despite the fact that differences between the two journals can in some measure be attributed to different editorial choices, it nevertheless brings out the significance of the large number of themes relating to the object of study in the Philosophical Transactions sample.

\section{Transitivity (processes)}

As pointed out above, in Systemic Functional Linguistics, transitivity is concerned with the patterns established in the clause by the process, the participants in the process, and any attendant circumstances. My analysis concerns the processes and participants of the finite clauses. I use a system which has five process types: material, mental, relational, verbal and existential. Each of these is given below with examples from the corpus where, as before, the relevant part is in bold. 
Material processes are actions or events of a physical nature:

And this Pïpe is still lengthened [...]

[...] what sorts of Grains are sown in your Country [...]

Mental processes are events of a cerebral type; these may be cognitive, perceptive, or affective:

[...] so this Author esteems it the best, not only for the durableness of the wood, and its large extent of usefulness in Carpentry and Joyners work; but also for the fitness of its leaves (besides their principal use for the food of Silkworms) to fatten Sheep, Goats, cowes, and Hoggs, only by boyling and mingling them with Bran.

The several kinds of the Soyls of England, being supposed to be, either Sandy, Gravelly, Stony, Clayie, Chalky, light mould, Heathy, Marish, Boggy, Fenny, or Cold weeping Ground, information is desired, what kind of soyls your Country doth most abound with, and how each of them is prepared, when employed for Arable?

Relational processes simply state a relationship between two entities, or between an entity and one of its properties; these may be attributive, identifying, or possessive:

It had four Eye-browes, placed in the manner exprest in Figure 4. by $a a, b b ; a a$ representing the lower, and $b b$, the upper Eye-lids.

The Scull being opened, both the Cerebrum and Cerebellum were bigg in proportion to the Body;

Verbal processes are processes of communication:

First, he teaches the Means of sowing, planting, and raising White Mulberryes (as the Foundation of Silkworks) shewing how many several wayes that may be done.

The Berryes themselves he commends as very excellent to fatten Poultry, and to make them lay Eggs plentifully.

Existential processes state the existence of an entity:

At the mouth or entry of the Adit there is a structure raised of Brick, like a Chimney, some 28. or 30 . foot high in all:

[...] especially since there is cause of hope, that a double Silk harvest may be made in one Summer in Virginia, without hindring in the least the Tobacco-Trade of that Countrey.

Table 4 gives the distribution of process types for the items in the issue of the Philosophical Transactions.

Table 4. Process types (Philosophical Transactions)

\begin{tabular}{|l|l|l|l|l|l|}
\hline & Mat & Ment & Rel & Verb & Exist \\
\hline Adits and Mines & 39 & 2 & 20 & 2 & 9 \\
\hline A Way to break Rocks & 31 & 1 & 38 & 2 & 2 \\
\hline Monstrous Head & 7 & 2 & 23 & 1 & 1 \\
\hline The Earl of Balcarres & 4 & 2 & 5 & 1 & 2 \\
\hline Breeding Silkworms & 54 & 6 & 34 & 17 & 4 \\
\hline Enquiries concerning Agriculture & 31 & 8 & 27 & 1 & 1 \\
\hline Total & 166 & 21 & 147 & 24 & 19 \\
\hline \% & 44 & 6 & 39 & 6 & 5 \\
\hline
\end{tabular}


As can be seen the two main process types are material and relational, showing that the main focus of these texts is on physical actions and events encoded in the material processes, and secondarily, description of the way things are encoded in the relational processes. As before, this might be considered fairly natural given the nature of the texts under study, but once again the significance of the figures can be brought out by comparison with those from the Journal des Sçavans.

Table 5. Process types (Journal des Sçavans)

\begin{tabular}{|l|l|l|l|l|l|}
\hline & Mat & Ment & Rel & Verb & Exist \\
\hline Codex Regularum & 11 & 10 & 22 & 7 & 3 \\
\hline Iosephi Laurenti & 1 & - & 8 & 2 & 1 \\
\hline Contradictiones Apparentes & 10 & 2 & 6 & 5 & 3 \\
\hline Divers Plaidoyez & 6 & 5 & 16 & 24 & 3 \\
\hline Reflexions & 1 & 5 & 6 & 4 & 1 \\
\hline La vie de la Ste Vierge Marie & 2 & 4 & 12 & 10 & 3 \\
\hline Lettre d'un Amy & - & 15 & 23 & 40 & 3 \\
\hline Total & 31 & 41 & 93 & 92 & 17 \\
\hline \% & 11 & 15 & 34 & 34 & 6 \\
\hline
\end{tabular}

Here, relational process is again important, showing that in the Journal des Sçavans, description is significant, but equally important is verbal process, showing that consideration of communication plays an important role. On the other hand, material process is relatively unimportant, so that physical events and actions do not seem to be of major importance in the French journal. Hence, while description, encoded in the relational processes is significant in both journals, interest in physical events and actions, encoded in the material processes, characterizes the Philosophical Transactions, while an interest in communication, encoded in the verbal processes, characterizes the Journal des Sçavans.

\section{Transitivity (participants in material process)}

Since use of material processes is a distinguishing feature of the Philosophical Transactions sample, it is of interest to look at these in more detail, by considering the types of participant which are associated with these processes. We can distinguish three types of agentive, or causal, participant. The actor is a conscious, or at least animate, entity which causes the process to take place.

$[. .$.$] so as one man may manage the Hammer [. .$. 

implicit, which uses it to cause the process to take place.

[...] the Fire within the Chimney doth still attract (so to speak) Air through the Tube [...]

A force is a non-conscious agent which causes the process to take place.

[...] the Silk that is in their Belly, will cause so extraordinary a heat in them, that it burns their gutts [...]

There are a further three participant roles that are relevant to this analysis. The affected is the participant that is modified or changed in some way by the process.

And who they are (if there be any in your Country) that have reduced Heaths into profitable Lands?

The result is the participant that is created by the process.

$[. .$.$] the first day they make only a Webb [...]$

And the range is the extent of the process, or a repetition in whole or in part of the process itself.

[...] when the Powder comes to take fire [...]

There are 18 different transitivity patterns in the examples of material process in the corpus. These are given in full in Appendix. However, many of these are marginal, occurring relatively infrequently. Table 6 lists those that occur more frequently, with a cut off point of ten occurrences (6\%).

Table 6. Most frequent transitivity patterns (material)

\begin{tabular}{|l|l|l|l|l|l|l|l|l|}
\hline & Adits & Rocks & Head & Balcarres & Silk & Enquiries & Tot & $\%$ \\
\hline Actor+MAT & 1 & 1 & 1 & - & 5 & 3 & 11 & 7 \\
\hline Actor+MAT+Affected & - & 4 & 1 & - & 12 & 2 & 19 & 11 \\
\hline Instrument+MAT+Affected & 4 & 6 & - & - & - & - & 10 & 6 \\
\hline Force+MAT & 6 & - & - & 1 & 3 & 2 & 12 & 7 \\
\hline Affected+MAT & 23 & 11 & 4 & - & 12 & 18 & 68 & 41 \\
\hline
\end{tabular}

I shall look at these in ascending order of frequency. The pattern instrument + material process + affected occurs ten times, thus accounting for $6 \%$ of the sample. In these, an instrument is being used to alter something; these all occur in the item on ventilation in mines. The following are examples.

The Grate or Cradle, which is narrower below than above, that the Ashes may the more easily fall, and the Air excite the Fire [...]

Which being done, and the Man retired, when the Powder comes to take fire, it will

first drive out the uppermost Wedge, as far as it will go [...]

[...] then the Fire tears the Rock to get forth [...]

There are 11 examples of the pattern actor + material process, which accounts for $7 \%$ of the sample. In these, there is an animate agent, but the process produces no outside effect. 
[...] so that men will there breath as surely as abroad [...]

This was the Head of a Colt, represented in the annexed Figure 4 first viewed by Mr.

Boyle, who went into the Stable where the Colt lay [...]

Care must be taken, that no Rats, Mice, Ants, or other Vermin, nor any Hens, or

Birds, come near the Seed [...] rounding). Here, a natural force is acting but not producing an effect in other entities. Half of these are in the item on ventilation in mines.

[...] this Ash-hole is immediately stopt so close, as Air cannot possibly get in at any part of it.

[...] a square hole of 8. or 9. inches every way, by which the Air enters to make the Fire burn:

He advertiseth, that they must be by no means interrupted in their work, to the end, that all the Silk, they have in their bellyes, may come out.

There are 19 examples of the pattern actor + material process + affected, which thus account for $11 \%$ of the sample. Here, an animate entity is causing some sort of change in its environment. However, it should be pointed out that 12 of these examples occur in the item on the French silk industry, but only three of these are human, most of the others being silkworms, which some may rate fairly low on the animate scale. Overall, of the 19 examples, ten are human and nine are non-human. The following are examples where the actor is non-human.

During which time this Insect leaves two Coats [...]

[...] the new creature thrusts out its head through the sharp end of the Case by a

Hole as big as its self.

[...] and the dayes following they thicken their Cases [...].

The following examples have human actors.

[...] so as one man may manage the Hammer, while another holds the Tool or Piercer.

[...] first viewed by Mr. Boyle, who went into the Stable where the Colt lay, and got the Head hastily and rudely cut off [...]

And who they are (if there be any in your Country) that have reduced Heaths into profitable Lands?

Finally we come to the pattern affected + material process, which is by far the most common, with 68 examples, accounting for $41 \%$ of the sample. In these cases, we have the entity which is modified or changed by the process functioning in subject position in the clause.

[...] as the Adit or Pit advanceth, by fitting the new Pipes so, as one end is always thrust into the other [...]

If it be hung in a Frame, or other convenient way, he that manageth it hath no more to do, but to pull it up at first as high as he can [...]

During which time this Insect leaves two Coats, both that of a Worm, whence 'tis changed into an Aurelia [...]

Probably, the commonest method of encoding an affected in subject position, is to use a verb in the passive voice, and this is the case in the three examples given above. However, this is not exclusively so, and there are other ways of encoding an affected as subject. The following are examples.

[...] by which meanes the whole Adit will be always filled with fresh Air, so that men will there breath as surely as abroad, and not only Candles burn, but Fire, when upon occasion there is use for it for breaking of the Rock. 
[...] and the Shutter made of Iron, or Wood that will not shrink, that it may shut very close [...]

The two flat sides that are contiguous, are to be greased or oyled, that the one may slip the more easily upon the other [...]

[...] and a piece of burning Match or Thread dipt in Brimstone or other such prepared combustible Matter, fastned to it, that may burn so long before it fire the Powder

$[\ldots]$ Transactions over three-quarters of the topical themes refer to the object of study. This was to become a permanent feature of the scientific journal article, and remained so in the physical sciences until towards the end of the nineteenth century, when it was overtaken by mathematical modelling as the favoured thematic choice. In the case of the biological sciences it has continued to be a major feature up to the present day (Banks 2008a). We have also seen that material process was the dominant process type, showing that interest was centred on physical actions and events, and that, moreover, the most common transitivity pattern was affected + material process. This again is something which has remained a permanent feature of the scientific journal article. This has commonly been attributed to the use of the passive, a feature first pointed out in Barber's seminal 1962 article (Barber 1962), and in many relatively early studies (e.g., Huddleston 1971) but still mentioned frequently today. However, we now realize that use of the passive is the result of a rather wider strategy, of which thematization is the driving force (Halliday 1988, 2004b, Halliday \& Martin 1993, Banks 2008a, 2008b). Use of the passive is simply one of the ways of encoding the transitivity pattern which places the affected in subject position before a material process. This is brought out here by the fact that almost $20 \%$ of the cases of this transitivity pattern are not, in fact, passive verbs.

The striking result of this is that it shows that some of the major features of the scientific journal article were already present in early issues of the Philosophical Transactions. Moreover, they were not merely present in an embryonic form, but in a form that was already fairly well established. Hence, we can say that the writers who contributed to the early Philosophical Transactions, and Henry Oldenburg in particular, played a fundamental role in establishing what was to become the norms of the scientific journal article. The style that was then laid down has repercussions that are still with us today. 


\section{BIBLIOGRAPHY}

Barber, C. L. 1962. "Some measurable characteristics of scientific prose”. In Behre, F. (ed.), Contributions to English Syntax and Philology. Stockholm: Almqvist and Wiksell, 21-43.

Banks, David. 2005. Introduction à la linguistique systémique fonctionnelle de l'anglais. Paris: L'Harmattan.

Banks, David. 2008a. The Development of Scientific Writing. Linguistic features and historical context. London: Equinox.

Banks, David. 2008b. "The significance of thematic structure in the scientific journal article, 1700-1980". In Nørgard, Nina (ed.), Systemic Functional Linguistics in Use, Odense Working Papers in Language and Communications 29. <http://www.sdu.dk/ /media/Files/Om_SDU/Instittuter/ISK/ Forkningspublikationer/OWPLC/Nr29/David\%>.

Banks, David. 2009a. "Starting science in the vernacular. Notes on some early issues of the Philosophical Transactions and the Journal des Sçavans, 1665-1700". ASp 55, 5-22.

Banks, David. 2009b. "Creating a specialized discourse: the case of the Philosophical Transactions". ASp 56, 29-44.

Banks, David. 2009c. "Notes on illustrations in some early issues of the Philosophical Transactions". In Slembrouck, Stef, Miriam Taverniers \& Micke Van Herreweghe (eds.), From will to well, Studies in linguistics offered to Anne-Marie Simon-Vandenbergen Ghent: Academia Press, 21-41.

Banks, David. Forthcoming a. "Les origines épistolaires de l'article scientifique”. In Banks, David (ed.), Aspects linguistiques du texte épistolaire. Paris: L'Harmattan.

Banks, David. Forthcoming b. "The beginnings of vernacular scientific discourse: genres and linguistic features in some early issues of the Journal des Sçavans and the Philosophical Transactions ".e-rea, Université de Provence Aix-Marseille 1.

Banks, David. Forthcoming c. "Les premières images de la revue scientifique : les Philosophical Transactions, 1665-1670". In Banks, David (ed.), L'image dans le texte scientifique. Paris: L'Harmattan. Bazerman, Charles. 1988. Shaping Written Knowledge. The genre and activity of the experimental article in science. Madison, WI: University of Wisconsin Press.

Bluhm, R. K. 1960. “Henry Oldenburg, F.R.S. (c. 1615-1677)”. In Hartley, Harold (ed.), The Royal Society. Its origins and founders. London: The Royal Society, 182-197.

Hall, Marie Boas. 2002. Henry Oldenburg. Shaping the Royal Society. Oxford: Oxford University Press.

Halliday, M. A. K. 1988. "On the language of physical science”. In Ghadessy, Mohsen (ed.), Registers of Written English, Situational factors and linguistic features. London: Pinter, 162-178.

Halliday, M. A. K. (rev. Christian M.I.M. Matthiessen). 2004a. An Introduction to Functional Grammar. $3^{\text {rd }}$. edn. London: Arnold.

Halliday, M. A. K. (ed. Jonathan J Webster). 2004b. The Language of Science (Collected works of M.A.K. Halliday Vol. 5). London: Continuum.

Halliday, M. A. K. \& J. R. Martin. 1993. Writing Science, Literacy and discursive power. London: Falmer Press. 
Huddleston, Rodney D. 1971. The Sentence in Written English: A syntactic study based on an analysis of scientific texts. Cambridge: Cambridge University Press.

\section{APPENDIXES}

\section{Transitivity patterns of material processes}

\begin{tabular}{|l|c|c|c|c|c|c|c|c|}
\hline & Adits & Rocks & Head & Balcarres & Silk & Enquiries & Tot & $\%$ \\
\hline Actor+MAT & 1 & 1 & 1 & - & 5 & 3 & 11 & 7 \\
\hline Actor+MAT+Affected & - & 4 & 1 & - & 12 & 2 & 19 & 11 \\
\hline Actor+MAT+Result & - & - & - & - & 5 & - & 5 & 3 \\
\hline Actor+MAT+Range & - & 1 & 1 & - & 5 & 2 & 9 & 5 \\
\hline Instrument+MAT & - & 2 & - & - & - & - & 2 & 1 \\
\hline Instrument+MAT+Affected & 4 & 6 & - & - & - & - & 10 & 6 \\
\hline Instrument+MAT+Result & - & - & - & - & - & 2 & 2 & 1 \\
\hline Force+MAT & 6 & - & - & 1 & 3 & 2 & 12 & 7 \\
\hline Force+MAT+Affected & 3 & - & - & 1 & 2 & - & 6 & 4 \\
\hline Force+MAT+Result & - & - & - & - & 1 & - & 1 & 1 \\
\hline Affected+MAT & 23 & 11 & 4 & - & 12 & 18 & 68 & 41 \\
\hline Affected+MAT+Range & - & 2 & - & - & 2 & - & 4 & 2 \\
\hline Result+MAT & - & 2 & - & - & 2 & - & 4 & 2 \\
\hline Range+MAT & 1 & 1 & - & 1 & 4 & 2 & 9 & 5 \\
\hline Range+MAT+Range & - & 1 & - & - & - & - & 1 & 1 \\
\hline MAT+Affected & 1 & - & - & - & - & - & 1 & 1 \\
\hline MAT+Force & - & - & - & 1 & - & - & 1 & 1 \\
\hline MAT+Range & - & - & - & - & 1 & - & 1 & 1 \\
\hline
\end{tabular}

\section{ABSTRACTS}

The Philosophical Transactions, the first academic journal in English, was first published in 1665. It was edited by Henry Oldenburg who based it on the correspondence which he received as secretary of the Royal Society. Analysis of the issue for 3 July 1665 shows that three-quarters of the topical themes refer to the object of study, whereas in the contemporaneous French publication the Journal des Sçavans the preferred themes relate to other texts and humans other than the author. The dominant transitivity processes in the Philosophical Transactions are material and relational, whereas in the Journal des Sçavans they are relational and verbal. Within material process the dominant pattern is that of "affected + material process". This shows that the features established in the early issues of the Philosophical Transactions were to affect the norms of scientific writing through the following centuries, and even up to the present day.

La première revue intellectuelle à paraître en anglais, les Philosophical Transactions, connaît une première édition en 1665. Son rédacteur, Henry oldenburg, en basait le contenu sur la correspondance qu'il recevait en tant que secrétaire de la Royal Society. Une analyse du numéro du 3 juillet 1665 révèle que les trois quarts des thèmes portent sur l'objet d'étude, tandis que dans une revue contemporaine, le Journal des Sçavans, les thèmes abordés concernent d'autres textes et des humains autres que l'auteur. Les procès les plus fréquents dans les Philosophical Transactions sont les procès matériels et relationnels, tandis que dans le Journal des Sçavans, les plus fréquents sont les procès relationnels et verbaux. Pour les procès matériels des Philosophical Transactions, le schéma le plus fréquent est celui du «affecté + procès matériel ». L'étude démontre que les traits établis dans les premiers numéros des Philosophical Transactions ont eu un effet sur la rédaction scientifique au cours des siècles qui ont suivi et jusqu'à présent. 


\section{INDEX}

Mots-clés: article de revue scientifique, Oldenburg (Henry), Philosophical Transactions, thématisation, transitivité

Keywords: Oldenburg (Henry), Philosophical Transactions, scientific journal article, thematic structure, transitivity

\section{AUTHOR}

\section{DAVID BANKS}

David Banks is Professor of English Linguistics at the Université de Bretagne Occidentale, Brest. He is Director of the M2 "Rédacteur-Traducteur", and organizes the linguistics option of the M2 “Textes, Images, Représentations". He is also the Director of ERLA (Équipe de Recherche en Linguistique Appliquée), which is part of EA 4240 HCTI, and Chairman of AFLSF (Association Française de la Linguistique Systémique Fonctionnelle). His current research interests include the comparison of French and English scientific writing in the late seventeenth century, and the application of Systemic Functional Linguistics to French. His recent publications include The Development of Scientific Writing, Linguistic features and historical context, London, Equinox, 2008. David.Banks@univ-brest.fr 